\title{
Sentinel lakes: a network for the study and management of mountain lakes in the French Alps and in Corsica
}

\author{
Birck, C., I. Epaillard, M.-F. Leccia, C. Crassous, A. Morand, C. Miaud, C. Bertrand, L. Cavalli, S. Jacquet, P. \\ Moullec, R. Bonnet, C. Sagot, E. Franquet, Y.M. Nellier, M.E. Perga, N. Cottin, C. Pignol, E. Malet, E. Naffrechoux, \\ C. Giguet-Covex, I. Jouffroy-Bapicot, D. Etienne, L. Millet, P. Sabatier, B. Wilhelm, B. Perren \& F. Arnaud
}

\section{Abstract}

High-altitude lakes are vulnerable ecosystems that require protection and sustainability management, although their overall functioning is still poorly understood. In France protected area managers and scientists are cooperating to address this problem. Their results show the huge diversity of these altitude lakes and imply specificities in their functioning and in the way they respond to stressors. Multidisciplinary studies on these ecosystems, on their individual history and the stressors they face, need to be developed in a number of lakes, alongside long-term monitoring surveys. This is the objective of the Sentinel lakes network.

\section{Introduction}

Mountain lakes of the French Alps and Corsica have been created by outstanding natural conditions and events and shaped by a long running interaction with humans. At elevations between 1800 and $2800 \mathrm{~m}$, in some cases ice-covered for eight months of the year, they constitute unique ecosystems in Europe. As they are distant from large urban areas and rather difficult to reach, mountain lakes are usually considered pieces of natural land preserved from the impacts of human activities. However, recent international studies have challenged this view, showing that they have been subjected to severe human stresses, on both local and global scales, sometimes for ages.

The objective of this article is to present a panel of ongoing studies, carried out within the framework of the French network Sentinel lakes, which investigates how mountain lakes respond to local or global stressors.

\section{Sentinel lakes: a network to help nature managers}

Mountain lakes are important for their biodiversity and the ecosystem services they provide. They also have great cultural and socioeconomic value, being the place for numerous human activities, such as tourism and outdoor activities, fishing, hydroelectricity production...

Lake managers face a dilemma since they are required to preserve the lakes' natural state while maintaining traditional human activities linked to these areas. Each of these activities is likely to trigger, in the short or longer term, substantial changes in the ecological state of these mountain lakes (Schindler 2001; Knapp 2001), especially since their peculiar properties (small size, extreme climate conditions, remoteness, small number of species) make them highly sensitive to any biological or chemical disturbances in the environment. Besides, these lakes have usually been subjected to severe and old anthropogenic pressures, the memory of which the lakes have kept within their sediments. The mountain catchment basins have been modified by human presence since Neolithic times

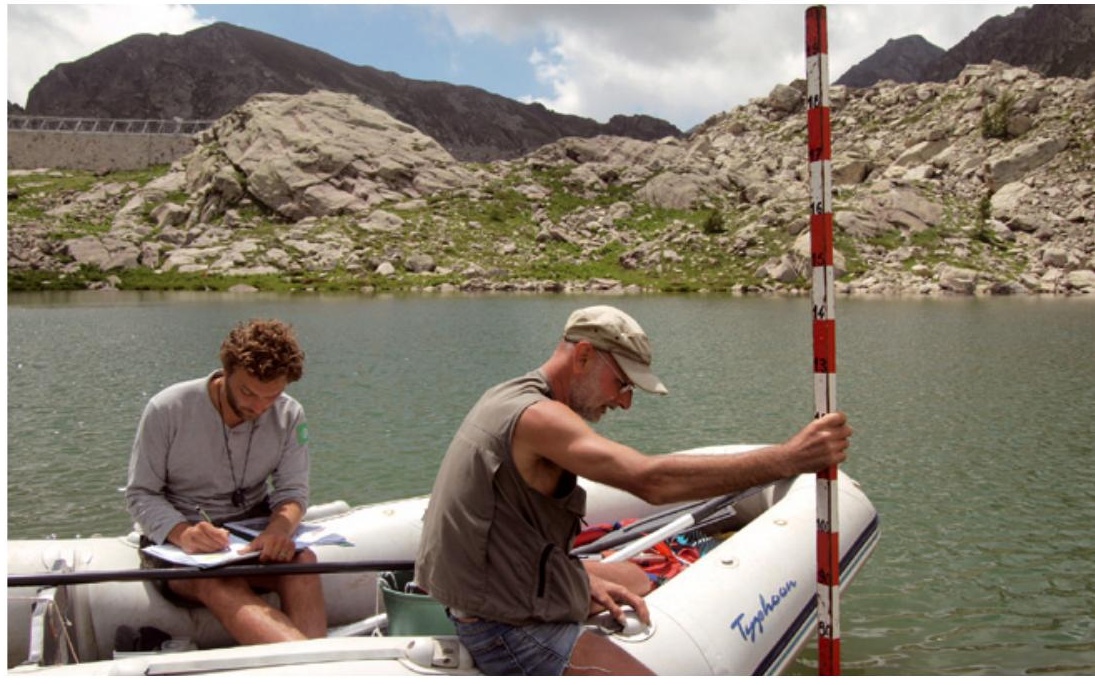

Figure 1 - Biological inventory on Lake Long Inférieur, Roya Valley. (C) P. Richaud

and especially from the Bronze Age onwards through deforestation, pasturing practices (Sturm et al. 1995; Giguet-Covex et al. 2011), mining activities (Brancelj 2000), and through fish stocking and fishing, for which documentation exists going back to the Middle Ages (Brancelj 2000; Pister 2001). More recently (second half of the $20^{\text {th }}$ century), tourism development could have also affected lake ecosystem functioning.

Among managers there is also a growing concern about the impact of global changes on the ecological state and future trajectories of these lakes. Indeed, some European mountain lakes have been shown to be contaminated by atmospheric inputs of nutrients (nitrogen fertilizer and phosphorus) or pollutants, such as metals (lead, mercury (Arnaud et al. 2004; Thévenon et al. 2011)) or persistent organic pollutants (PAH or pesticide residues, DDE), carried over long distances (Battarbee 2005). They were also repeatedly shown as affected by climate change (EMERGE project, 2000, EU FP5).

Rangers and scientists surveying mountain lakes in the French Alps and in Corsica have observed recent changes in their status, such as an increase in the algal production and the appearance of cyanobacteria (Cazaubon 2006), reduced water quality, hypoxic con- 


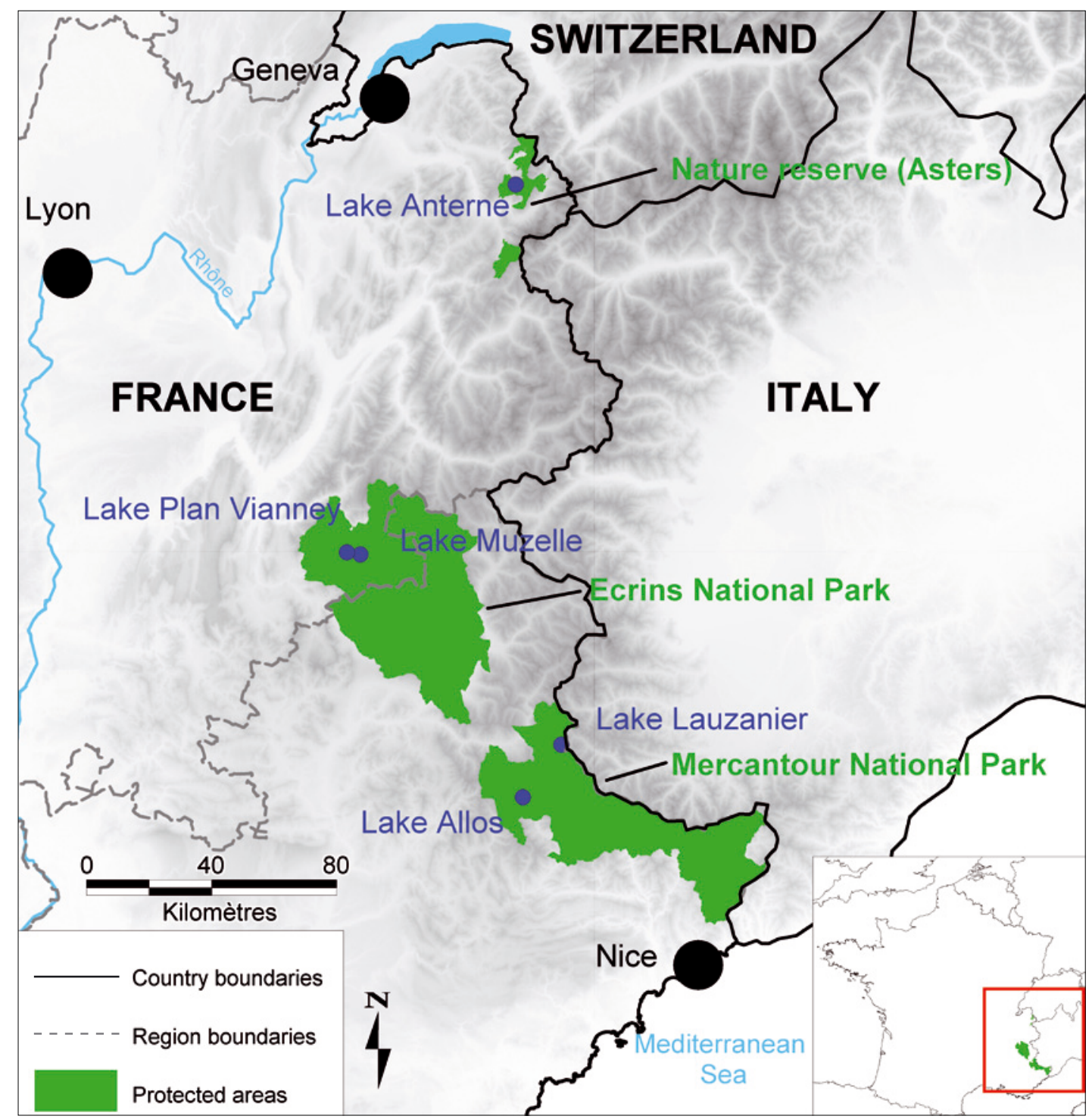

Figure 2 - Lakes and protected areas mentioned in this article. Sources: 2013-IGN, Muséum national d'Histoire naturelle, Asters - copie et reproduction interdite; all rights are with Asters

ditions at lake bottom (Giguet-Covex et al. 2012), introduction and loss of species. But there is still a lack of knowledge about the reasons for these changes, the impact of the multistressors on lakes and about the means to protect or restore them.

In this context ecosystems managers plus scientists from physical, biological and social sciences have joined a network called Sentinel lakes. Its aim is to enhance research, information and data sharing on mountain lake biodiversity and functions in a context of global change. It is coordinated by Asters (which manages of the nature reserves of Haute-Savoie - cf. Info box) and includes researchers from universities, from the National Centre for Scientific Research and INRA (National Institute for Agricultural Research) as well as managers and stakeholders from French $\mathrm{Na}$ tional Parks, National Nature Reserves, Water Agency, French National Fishery Federation and ONEMA (French Water and Aquatic System Board) from the French Alps and Corsica.

\section{From knowledge to management}

The restoration of the lakes' natural function is one of the aims outlined in the Charter of the Mercantour National Park. In this framework and in relation to the ALCOTRA 2007-2013 transboundary project Mercantour-Alpi Marittime Generalised Biological Inventory, special attention has been paid to these hydrosystems in order to provide a picture of the initial state of their biodiversity.

These inventories focus on aquatic invertebrates, amphibians and fish, macrophytes and algae, and have already been set up on more than 30 lakes. On completion of this programme, the park aims to study one or several lakes in each valley that will be representative of the park's lakes in terms of altitude, surface area and trophic level. At the same time, major efforts have been made to collect, validate and format all available biological, but also mesological and socio-economic data for each lake. This work has been planned to enable coordinated management between stakeholders 


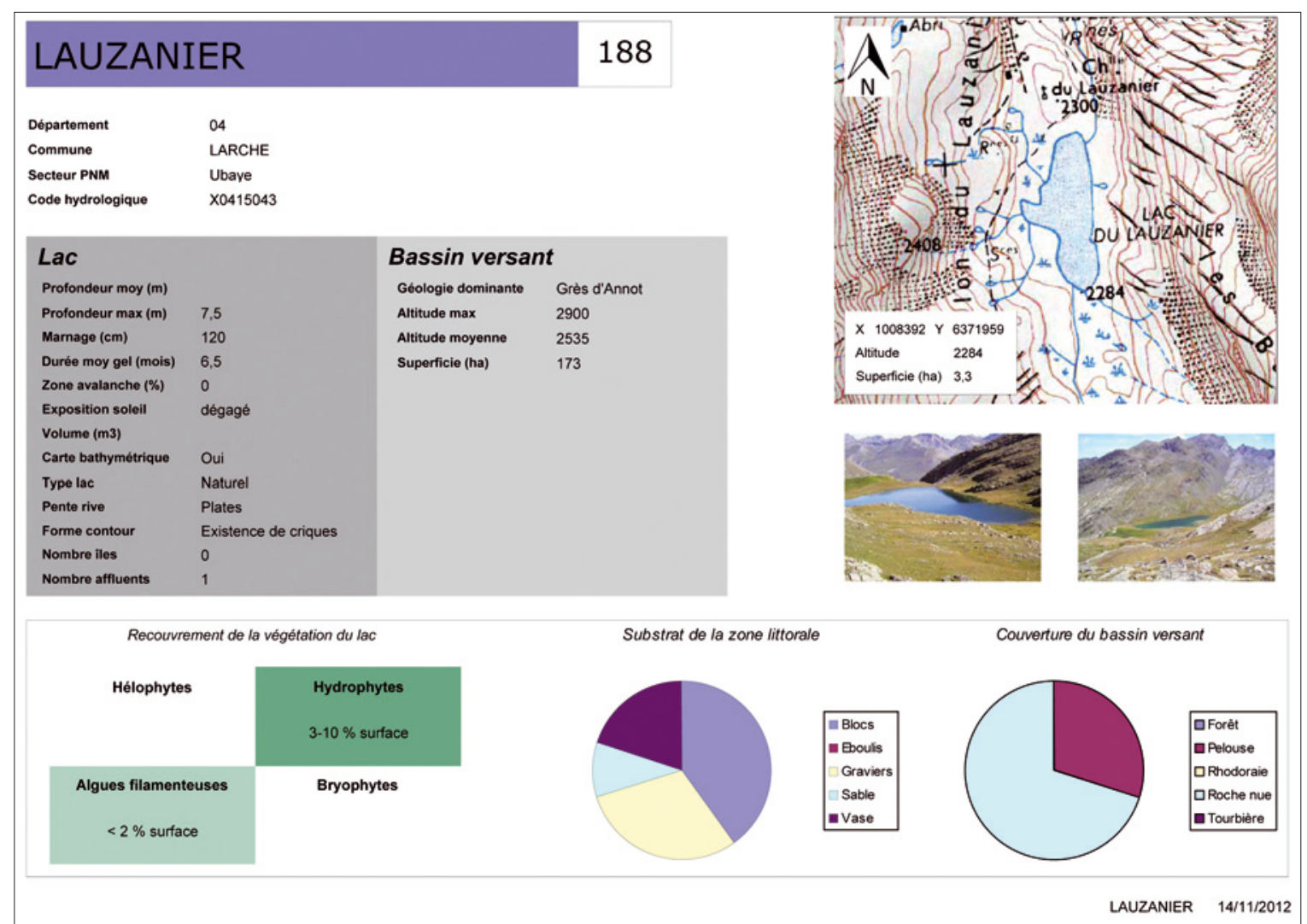

Figure 3 - Example of lake documentation sheet

and users (fishermen, shepherds, hikers, etc.) and their federation or representatives.

Inventory results, which still need to be completed, have already given the park authorities an idea of the specific richness and composition of the living community with the registration of several patrimonial species (Somatochlora alpestris, Alytes obstetricans and others). The plan for the next few years is to continue developing studies and inventories on these taxa with the aim of monitoring lakes to a greater extent and establishing certain land management operations (e.g. reducing organic waste from cattle and mountain huts and a stop on stocking lakes with young fish) to assess their impact on biodiversity. Some comparative approaches are also being set up to involve all of the lakes and new investigation methods (barcoding) will be tested.

\section{Biodiversity in the lakes}

Planktonic diversity and impacts of fish introduction in high-altitude lakes (French Alps)

To improve their management Ecrins National Park has launched studies for a better knowledge of alpine lakes functions and impacts of fish introduction. A collaboration with IMBE (Institut Méditerranéen de Biodiversité et d'Ecologie) initiated in 1992 highlighted that in certain lakes, as food resources are limited, two years are generally necessary for the maturation of the gonads of Salvelinus alpinus (Figure 4, Cavalli \& Chappaz 1996). This was demonstrated by the presence of two female fish groups, one with high gonadosomatic index (GSI = Gonad weight / fish weight) and another one with low gonadosomatic index. Moreover, this approach revealed the impact of introduced fishes (topdown control / predation effect) on zooplankton communities (planktonic crustaceans and rotifers). In cold lakes, when food resources are scarce, fish predation had a direct impact on the large microcrustacean zooplankton; in contrast, in warmer lakes, food resources are more abundant and the lower fish predation on crustaceans leads to an important crustacean predation on rotifers, with an effect on some rotifer species form (Cavalli et al. 2001).

\section{Infobox}

\section{Asters}

Initiated by the Scientific Committee of the Nature Reserves of HauteSavoie, Asters has implemented a monitoring on 5 of the mountain lakes on the territory that started 15 years ago. Chemical, physical and biological parameters are measured each year by the rangers to assess the evolution of the ecosystem. One of these lakes is more closely surveyed by the scientific partners with the aim of better understanding the ecosystem and how it works.

As a natural consequence the partners of the network have given Asters the mission to encourage exchanges and to coordinate activities like the development of a standardized protocol.

\section{Contact}

carole.birck@asters.asso.fr 


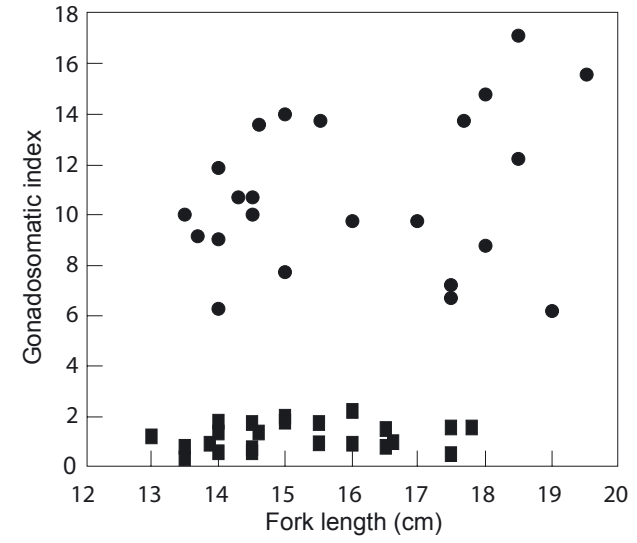

Figure 4 - Relationship between gonadosomatic index and length for female mature (•) and immature (-) Arctic char in Muzelle lake in October. Reprint from Cavalli \& Chappaz (1996), published in Journal of Fish Biology

This collaboration allowed adopting valuable management measures (dates, species, sizes) for fish stocking. Since 2005 a long-term survey of planktonic trophic food webs has been conducted in collaboration with the park rangers and ONEMA. The structural and functional diversities were characterized for the French Alps. The study was based on a large variety of highly constrained ecosystems (different landscape and internal characteristics) and revealed high planktonic heterogeneity. Recently flow cytometric analyses of viral, bacterial and phytoplanktonic components have allowed observing planktonic biodiversity and confirmed the heterogeneity between lakes (Figure 5).

On the left panel, based on chlorophyll $a$, fluorescence and side scatter (related mainly to shape and size), at least five different dot populations corresponding to different phytoplanktonic groups (referred to as phyto- $x$ ) can be identified. On the right panel, following nucleic acid staining, and based on DNA-dye fluorescence and side scatter, three groups of viruses (referred to as virus-like particle or VLP- $x$ ) and two groups of heterotrophic prokaryotes (mainly bacteria named bact- 1 \& bact- 2 ) can be identified. This figure illustrates the importance of the abundance and the diversity of some key planktonic groups in the functioning of mountain lakes.
The long-term survey revealed the complex interactions between global (climatic change, atmospheric deposition) and local stressors (pastures, mountain huts) and their impacts on the structure of food webs and in turn on the ecosystem services. Water chemical analysis (N, P, Carbon), temperature records and atmospheric deposition analyses ( $\mathrm{Ga}$, In, Sb, Tl, Ge, $\mathrm{Ag}, \mathrm{Se}, \mathrm{Pb}, \mathrm{Cu}, \mathrm{Ni}, \mathrm{Cd}, \mathrm{As} . .$.$) were conducted in certain$ lakes.

Ecology of amphibians in high-altitude lakes and interactions with introduced fishes

The introduction of non-native fishes into ponds and lakes is a common practice throughout the world, even in protected areas like national parks. In the Alps many lakes have been stocked with different species of carnivorous fish such as salmonids. The objective of the study is to understand the potential impact of introduced fishes on the Alpine amphibian community. The first step is to describe the ecology of Alpine amphibians, by applying a standardized sampling protocol to infer species occurrence according to aquatic and terrestrial habitat characteristics in a significant number of aquatic sites. The knowledge of stocking practices will allow comparing areas differing historically in the presence of fishes. The presence of at least two amphibian species greatly varying in their life history traits (frog and newt) will allow comparing the causal effect of fish predation on amphibian life stages and ultimately population dynamics. The understanding of the complex relations between fish presence and amphibian population dynamics will help to propose management actions for both amphibian conservation and sport fishing practices. The standard protocol will also permit to infer temporal amphibian population trends that can be connected with egg recovery plans and more global environmental changes such as climate.

\section{PCB contamination in high-altitude lakes}

Polychlorobiphenyls (PCBs) are synthetic organic pollutants the production and use of which have been banned for over 35 years. However, these compounds
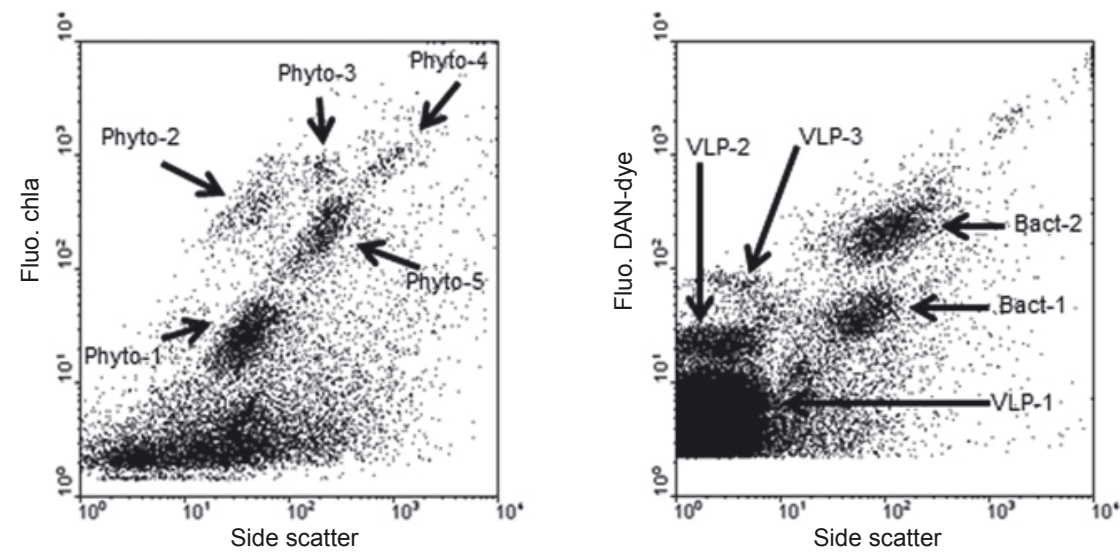

Figure 5 - An example of flow cytometry cytograms revealing different phytoplankton, bacterial and viral groups 
present several properties that still make them major ecological issues. First, PCBs are highly stable, resistant to degradation. As a consequence, they persist in the environment even 35 years after interdiction and can still cause local sanitary problems. Second, their semivolatility is responsible for their atmospheric longrange transport and widespread distribution, even in remote ecosystems such as Polar regions and highaltitude lakes. Lastly, PCB hydrophobicity promotes their transfer and bioaccumulation in food webs, up to fish. Besides, PCBs represent a wide range of congeners with specific physico-chemical properties and can then be regarded as model compounds for understanding the general risks related to other persistent organic pollutants.

While the atmospheric transport of PCBs, basically driven by physical rules of distillation / deposition, is well understood, the processes that occur between PCB deposition and fish contamination have been so far poorly studied. As a matter of fact, recent studies performed on European lakes exposed to similar atmospheric deposition highlighted, but failed to explain, substantial differences in the PCB contamination of their fish communities. Our hypothesis in this ongoing work is that this variability arises from the biological processes and pathways by which deposited PCBs are transferred within the food web to the fish compartment. Hence, two lakes submitted to similar atmospheric inputs of PCBs but different food web composition might ultimately exhibit different fish contamination, because of different abilities of their food web to transfer PCBs.

The study sites are two lakes in Ecrins National Park (Lake La Muzelle, Lake Plan Vianney). These two lakes are located close to each other at similar altitudes but are characterized by different trophic status and food webs. PCBs are measured seasonally in major geochemical and biological compartments, ranging from dissolved, size-fractioned organic matter, sediment up to zooplankton, macro-invertebrates and fishes.

Results obtained so far confirmed that in spring fish from Plan Vianney have PCB levels that are twice those in La Muzelle. Fish contamination with PCBs occurs essentially during snowmelt, suggesting that the interaction between the release of PCBs stocked in the winter snow and the start of algal growth is a crucial step for the transfer of the PCBs into the lake food web. Indeed, in this particular season, PCBs are distributed differently in the organic matter size fractions between the two lakes, confirming the role played by the ecological processes in the mobilization of PCBs. Current and future research aims at a stronger sampling effort during snowmelt in order to refine our understanding of the ongoing interaction between released PCBs and biological components, ex-situ experiments on lake sediments to apprehend PCB bioavailability and a paleolimnological reconstruction of the historical PCB contamination of these lakes.

\section{Past evolution of three high-altitude lake ecosystems (French Alps)}

Reconstructing and understanding past ecological changes of high-altitude Alpine lakes could be helpful for improving their management. Towards this goal lake sediments represent interesting archives as they record past changes in their biological, biogeochemical and physical states. They also allow accessing the factors driving such changes.

Sediment cores from three different lakes across the French Alps (Lake Anterne, Lauzanier and Allos, at $2063 \mathrm{~m}, 2285 \mathrm{~m}$ and $2228 \mathrm{~m}$, respectively) were studied by multiproxy approach with sedimentological, geochemical (mineral and organic) and biological analyses (Figure 6). Results showed that all three lakes underwent changes in their productivity and in bottom oxygen concentrations. However, these changes occurred at different periods and were triggered by factors that varied between lakes.

For example, the productivity of Lake Lauzanier increased from the Little Ice Age (LIA, 1350-1900 AD), first as a result of the combined effects of an intense pasturing activity and a relatively high hydrological activity (Figure 6), increasing the transfer of nutrients from the watershed to the lake. However, atmospheric nitrogen deposits are thought to be responsible of the lake's high trophic level and the degradation of oxygenation conditions, recorded in this lake from the late 1950s (Figure 6).

In the case of Lake Anterne, the main change in lake productivity has been recorded from 1980 and is probably due to the acceleration of global warming in the Alps, in particular through the increase in the icefree period (Figure 6).

Primary productivity in Lake Allos increased around 1920 , probably in response to the fish introduction. Since the 1980s lake water quality and oxygenation conditions have been improving (Figure 6). Although the pasturing pressure and hydrological activity were high during the LIA at Allos, they did not encourage lake productivity as observed in Lake Lauzanier. An explanation for such different responses to similar environmental factors might lie in the fact that the watershed of Lake Allos is more sensitive to erosion than that of lake Lauzanier. It is thus possible that, beyond a turbidity threshold, productivity is limited by the lack of light in realizing photosynthesis.

In conclusion, this study underlines a recent decrease of local pressures on lake ecosystems. In contrast, we observe changes attributed to the impact of global forcing factors on these remote lakes.

\section{Conclusion}

There is evidence that, in spite of their remote position, high-altitude Alpine lakes have undergone modifications triggered by human pressure. The studies undertaken in lakes of the French Alps have dem- 


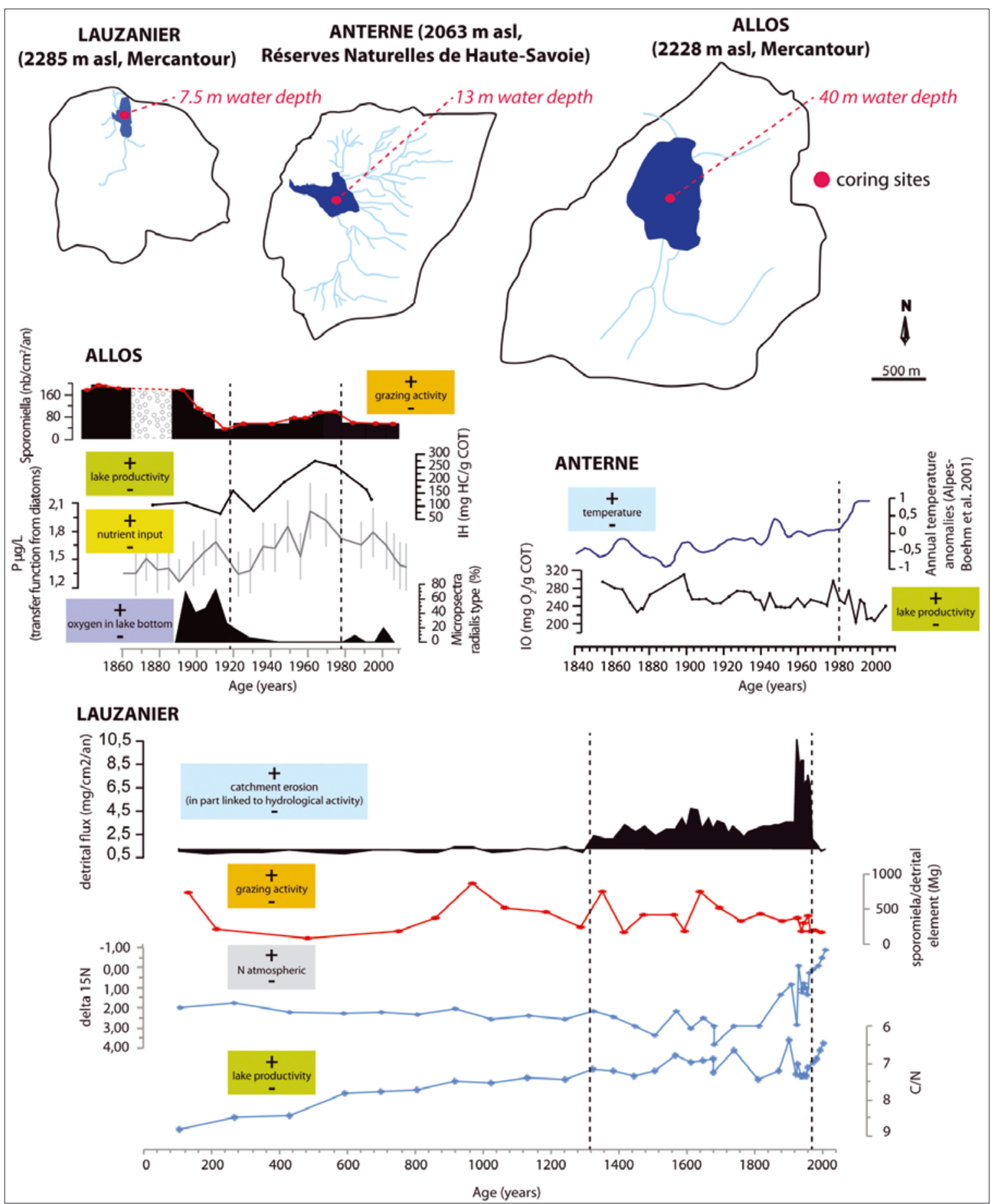

Figure 6 - Representation of catchments, lakes and coring sites. The different curves correspond to indicators reflecting past lake ecosystem evolutions (lake productivity through indices of organic matter quality (IH, bydrogen index; IO, oxygen index; $C / N$, carbon-to-nitrogen ratio); oxygenation conditions are also presented in comparison with forcing factors affecting them (temperature, erosion, grazing activity and atmospheric nitrogen deposits, per lake)

onstrated the impacts on biodiversity of local activities such as fish stocking but also the consequences of atmospheric pollution (PCBs, Nitrogen...) on the characteristics of the lakes.

Multidisciplinary research can help to understand how the ecosystem responds to these multi-stressors conditions. Monitoring of a large number of mountain lakes and sharing the results within the network will also enable better protection and management of these habitats.
Other scientists and / or protected areas managers working on or interested in the subject are kindly invited to contact us.

\section{References}

Arnaud, F., M. Revel-Rolland, D. Bosch, T. Winiarski, M. Desmet, T. Tribovillard \& N. Givelet 2004. A 300 year history of lead contamination in northern 
French Alps reconstructed from distant lake sediment records. Journal of Environmental Monitoring 6: 448-456.

Battarbee, R.W. 2005. Mountain lakes, pristine or polluted? Limnetica 24: 1-8.

Brancelj, A., M. Sisko, I.R. Brancelj, Z. Jeran \& R. Jacimovic 2000. Effects of land use and fish stocking on a mountain lake - evidence from the sediment. $\mathrm{Pe}$ riodicum Biologorum 102: 259-268.

Cavalli, L. \& R. Chappaz 1996. Diet, growth and reproduction of the artic charr (Salvelinus alpinus (L.)) in a high alpine lake: Muzelle (Oisans, France). Journal of Fish Biology 49: 953-964.

Cavalli, L., A. Miquelis \& R. Chappaz 2001. Combined effects of environmental factors and predatorprey interactions on zooplankton assemblages in five high alpine lakes. Hydrobiologia 455: 127-135.

Cazaubon, A. 2006. Études des algues de cinq lacs d'altitude de Corse (Nino, Melo, Maggiore, Bastani, Cavacciole). Étude réalisée dans le cadre de l'appel d'offre de l'Office de l'Environnement de la Corse.

Giguet-Covex, C., F. Arnaud, J. Poulenard, J.-R. Disnar, C. Delhon, P. Francus, F. David, D. Enters, P.-J. Rey \& J.-J. Delannoy 2011. Changes in erosion patterns during the Holocene in a currently treeless subalpine catchment inferred from lake sediment geochemistry (Lake Anterne, $2063 \mathrm{~m}$ asl, NW French Alps): the role of climate and human activities. The Holocene 21: 651-665.

Giguet-Covex, C., B. Perren, M.E. Perga, V. Vernaux, I. Jouffroy-Bapicot, D. Etienne, L. Millet, P. Sabatier, J.-L. Reyss, F. Arnaud \& B. Wilhelm 2012. Observatoire et rétro-observatoire de l'état écologique des plans d'eau d'altitude : réflexions sur la notion d'état de référence et évaluation des facteurs de dégradation des lacs d'altitude. Rapport final. Action n ${ }^{\circ} 27$ du Programme 2011 au titre de l'accord cadre Agence de l'Eau ZABR.

Mc Gowan et al. 2011. Interdecadal declines in flood frequency increase primary production in lakes of a northern river delta. Global Change Biology 17: 1212-1224.

Knapp, R.A., K.W. Matthews \& O. Sarnelle 2001. Resistance and resilience of alpine lake fauna to fish introductions. Ecological Monographs 71: 401-421.

Pister, E.P. 2001. Wilderness fish stocking: History and perspective. Ecosystems 4: 279-286.

Schindler, D. E., R.A. Knapp \& P.R. Leavitt 2001 Alteration of nutrient cycles and algal production resulting from fish introductions into mountain lakes. Ecosystems 4: 308-321.

Sturm, M. \& A.F. Lotter 1995. Sédiments lacustres: des archives révélatrices d'origine naturelle et anthropiques. EAWAG news 38f: 6-9.

Thevenon, F., S. Guédron, M. Chiaradia, J.-L. Loizeau \& J. Poté. 2011. (Pre-)historic changes in natural and anthropogenic heavy metals deposition inferred from two contrasting Swiss Alpine lakes. Quaternary Science Reviews 30: 224-233

\section{Authors}

Birck, C. \& I. Epaillard: Asters, Conservatoire des espaces naturels de Haute-Savoie

Asters is the manager of the nine nature reserves located in Haute-Savoie, France. Its other missions are to develop environmental expertise, protect and manage habitats and species, and to inform and raise awareness of the general public.

\section{A biological inventory of the Mercantour National Park Lakes}

Leccia, M.-F., C. Crassous \& A. Morand: Parc National du Mercantour, 23 rue d'Italie, 06000 NICE, France.

Ecology of amphibian in high altitude lakes and interactions with introduced fishes

Miaud, C.: UMR 5175-CNRS EPHE Laboratoire de biogéographie et écologie des vertébrés. Université de Montpellier. 1919 route de Mende 34293 Montpellier Cedex 5, France.

An example of the impacts of fish introduction in altitude lakes

Bertrand, C. ${ }^{1}$, L. Cavalli ${ }^{1}$, S. Jacquet ${ }^{2}$, P. Moullec ${ }^{3}$, R. Bonnet ${ }^{4}$, C. Sagot ${ }^{4} \&$ E. Franquet ${ }^{1}$

Contamination by PCB in high altitude lakes

Nellier, Y.M. ${ }^{5,2}$, M.E. Perga ${ }^{2}$, N. Cottin ${ }^{5}$, C. Pignol ${ }^{6}$, E. Malet ${ }^{6} \&$ E. Naffrechoux ${ }^{5}$

Past evolution of three high altitude lake ecosystems (French Alps)

Giguet-Covex, C. ${ }^{6}$, M.E. Perga ${ }^{2}$, I. Jouffroy-Bapi$\cot ^{7}$, D. Etienne ${ }^{2}$, L. Millet ${ }^{7}$, P. Sabatier ${ }^{6}$, B. Wilhelm ${ }^{6}$, B. Perren ${ }^{7} \&$ F. Arnaud

${ }^{1}$ UMR7263 IMBE, Institut Méditerranéen de Biodiversité et d'Ecologie, Equipe Ecologie des Eaux Continentales, Aix-Marseille Université, Avenue Escadrille-Normandie-Niemen 13397 Marseille cedex 20, France.

${ }^{2}$ UMR0042 - INRA, CARRTEL, Centre alpin de recherche sur les réseaux trophiques et les écosystèmes limniques, Thonon les bains, 74203, France

${ }^{3}$ ONEMA-SD05, Parc d'Entraigues, 05200 EMBRUN, France.

${ }^{4}$ Parc National des Ecrins, Domaine de Charance, 05000 GAP, France.

${ }^{5}$ LCME, Laboratoire de chimie moléculaire et environnement, Université de Savoie. Le Bourget du Lac, 73376, France

${ }^{6}$ UMR5204 - CNRS, EDYTEM, Environnement et dynamique des territoires de montagne, Université de Savoie. Le Bourget du Lac, 73376, France

${ }^{7}$ UMR6249 - CNRS, Chrono-environnement, Université de Franche-Comté, CNRS, 16 route de Gray, 25030 Besançon Cedex, France 